\title{
MORPHOLOGICAL ASSESSMENT OF WOUND HEALING AFTER CRYODESTRUCTION OF SKIN USING AN AQUEOUS COLLOIDAL SOLUTION OF C60 FULLERENES
}

DOI: 10.36740/WLek202004104

\author{
Oleksandr 0. Vlasov ${ }^{1,2}$, Gennadiy 0. Kovalov ${ }^{1}$, Mykhailo S. Myroshnychenko ${ }^{3}$ \\ ${ }^{1}$ INSTITUTE FOR PROBLEMS OF CRYOBIOLOGY AND CRYOMEDICINE OF THE NATIONAL ACADEMY OF SCIENCES OF UKRAINE, KHARKIV, UKRAINE \\ ${ }^{2}$ V.N. KARAZIN KHARKIV NATIONAL UNIVERSITY, KHARKIV, UKRAINE \\ ${ }^{3}$ KHARKIV NATIONAL MEDICAL UNIVERSITY, KHARKIV, UKRAINE
}

\begin{abstract}
The aim is to assess the morphological state of a cold skin wound in an experiment, using an aqueous colloidal solution of (60 fullerenes.

Materials and methods: An experimental study was conducted in 30 six-month-old male rats divided into three groups, 10 individuals in each group: group I included rats that did not undergo any manipulations; group II was represented by rats which underwent a cold wound simulation on the lateral thigh surface; group III was represented by rats who had a simulated cold wound followed by introduction of an aqueous colloidal solution of 60 fullerenes at a dose of $0.1 \mathrm{mg} / \mathrm{kg}$ for 5 days into the abdominal cavity, starting from the cryodamage day. Animals of all groups were removed from the experiment on days 7, 14 and 21.

The material for the morphological study was skin with underlying soft tissues. The resulting sample was studied, using histological, histochemical, morphometric and statistical research methods.

Results: 60 fullerenes stimulate proliferative activity in the epidermis, located in the wound marginal regions or covering the regenerate surface, which leads to an increase in epithelial layer thickness by 2.6, 2.6, 2.5 times on 7, 14 and 21 days; promotes faster cleansing of the wound from necrotic tissue, reducing the thickness of the zone of primary necrosis on days 7, 14 and 21 by 1.3 times by increasing the demarcation zone on days 7, 14 and 21 by 1.4, 1.4 and 2, 2 times; reduces the thickness of the secondary necrosis area on 7, 14 and 21 days by 1.4, 1.5 and 1.3 times; accelerates filling of the wound defect with granulation tissue, the layer thickness of which increases by $2.3,2.2$ and 1.4 times on the 7th, 14th and 21st days, respectively; reduces the severity of hemodynamic disorders and cell infiltration in the wound defect adjacent tissues of the dermis, hypodermis with the underlying muscle tissue.

Conclusions: A comprehensive morphological study of the experimental material indicates that the injection into the abdominal cavity of an aqueous colloidal solution of C60 fullerenes activates reparative processes in the skin cold wounds, which go through all the classical stages.
\end{abstract}

KEY WORDS: cryodestruction, cold wound of the skin, morphology, reparative processes, aqueous colloidal solution of C60 fullerenes

Wiad Lek. 2020;73(4):642-647

\section{INTRODUCTION}

The impact of low temperatures on skin is widespread in medical practice and has a long history. The cryosurgical method is well-established in the treatment of various benign, precancerous and malignant skin lesions. The benefits of cryosurgery include high success rates, minor side effects, relative ease of implementation and reasonable cost [1]. In this case, cold wounds always arise after cryosurgical treatment. It is one of the long-studied issues, which until now has been comprehensively investigated and continues to be relevant. Experimental and clinical studies in this direction indicate that the results of cold skin wounds treatment cannot be considered optimally effective today. In this regard, the search for new, effective methods and means of treating cold skin wounds remains appropriate and relevant [2]. The effectiveness of wounds treatment is known to be determined by the qualitative and quantitative morphological characteristics of the formed regenerate, the features and duration of the wound process phases [2].
The past decade was marked by deep interest of researchers and medical practitioners in the use of fundamentally new and original structures in medicine - fullerenes, especially C60 fullerenes [3]. Fullerene $\mathrm{C} 60$ is a molecule close to a spherical shape with a diameter of $0.72 \mathrm{~nm}$. The surface of fullerene C60 consists of 60 carbon atoms, interconnected by single and double chemical bonds. C60 fullerenes are synthesized using available chemical methods. They are characterized by high chemical stability and unique properties [4].

At present, it is known that C60 fullerenes have immune-modulating, antibacterial and antiviral effects. They are able to interact directly with the lipid matrix of biomembranes and penetrate the cell [5]. Fullerenes effectively trap free radicals and act as powerful antioxidants [6], which improves muscle tissue endurance [6] and helps to slow down the aging process [7]. They also have an anti-inflammatory effect [8].

Some scientists emphasize that the most prominent effects of fullerene $\mathrm{C} 60$ are protection from radiation-in- 
duced injury, neuroprotection, drug and gene delivery, anticancer therapy, adjuvant within different treatments, photosensitizing, sonosensitizing, bone reparation and biosensing [9].

There are few publications devoted to the study of C60 fullerenes effect on regenerative processes in bone tissue $[10]$ and in burn wounds of the skin $[11,12]$, the results of which, at times, are contradictory and are presented in the form of hypotheses. Given the unique properties of C60 fullerenes, the study of their possible use in improving the results of wounds treatment after cryodestruction of the skin looks promising. However, there are no data on the effect of C60 fullerenes on the healing processes of cold skin wounds in the scientific literature, which undoubtedly actualizes such studies.

\section{THE AIM}

The purpose of the study is to evaluate in an experiment the morphological state of a cold skin wound using an aqueous colloidal solution of fullerene C60.

\section{MATERIALS AND METHODS}

The studies were conducted at the Institute for Problems of Cryobiology and Cryomedicine of the National Academy of Sciences of Ukraine on 6-month-old hairless male rats. The experiments were carried out according to the regulations approved by the Bioethics Committee of the Institute for Problems of Cryobiology and Cryomedicine of the National Academy of Sciences of Ukraine, developed in accordance with the "General principles of experiments on animals» approved by the Third National Congress of Bioethics (Kyiv, Ukraine, 2007) and agreed with the provisions of the European Convention on the protection of vertebrate animals used for experimental and other scientific purposes (Strasbourg, France, 1986).

During the study, three groups of 10 animals were formed: group I included rats that did not undergo manipulations; animals in groups II and III underwent to cryodestructing on the lateral surface of the thigh with an instrument that allowed to maintain the temperature of the working surface of the applicator during the operation not higher than $-50^{\circ} \mathrm{C}[13]$. The diameter of the cryoeffect was $10 \mathrm{~mm}$. The cryoprescription time was $120 \mathrm{~s}$. After cryodestruction rats in group II were injected saline solution into the abdominal cavity; rats of group III - an aqueous colloidal solution of C60 fullerenes at a dose of $0.1 \mathrm{mg} / \mathrm{kg}$ into the abdominal cavity for 5 days, starting from the cryodamage day. The animals in all groups were removed from the experiment on days 7, 14 and 21 .

Fragments of intact skin in group I with underlying soft tissues from the thigh area, in groups II and III - fragments of skin with underlying soft tissues from the femoral region directly from the cryogenic lesion zone were the material for the morphological study. The resulting material was fixed in a $10 \%$ formalin solution. Formalin-fixed tissues were compared in was achieved by passing through alco- hols of increasing concentration, Nikiforov liquid (96\% alcohol and diethyl ether in a 1: 1 ratio), chloroform and paraffin filling. Serial sections $4-5 \times 10^{-6} \mathrm{~m}$ thick were prepared from the blocks. Microspecimens stained with hematoxylin and eosin, picrofuchsin according to van Gieson, according to Mallory were studied on an Olympus BX-41 microscope (Japan), followed by processing with the Olympus DP-soft version 3.1 software package. During a morphometric study we determined thickness of the epithelial layer (in group I in an arbitrary place, in groups II and III from the wound marginal regions or from the regenerate region), as well as the area of primary and secondary necrosis, demarcation leukocyte shaft, and a layer of granulation tissue.

The statistical analysis was performed the Statistica 6.0 and Microsoft Excel 2003 software package. Nonparametric methods were used to compare the parameters (Mann-Whitney U-test, Kruskal-Wallis test). The significance of the differences between the average values of the indices in the groups was taken at a significance level of $\mathrm{p}<0.05$.

\section{RESULTS AND DISCUSSIONS}

When studying microspecimens in groups II and III on days 7,14 and 21 , a wound defect with a characteristic multilayer structure was revealed in the cryoexposure region (fig. 1).

In groups II and III, the entire surface of the wound defect was represented by necrotic fragments of the epidermis, dermis and hypodermis, which were components of the primary necrosis area. Currently, it is believed that occurrence of this area is associated with direct destruction of cells under the influence of low temperature [14]. There is still no clear concept of the mechanism of primary damage to biological tissues during cryodestruction and the occurrence of a zone of primary necrosis. Many cryosurgeons traditionally hold a theory of P. Mazur on the two-phase mechanism of cryodestruction, according to which tissue destruction is caused by intracellular and extracellular crystallization of water, followed by its recrystallization, due to which cell membranes are damaged. Then destruction occurs, followed by cell necrosis [14]. However, since this theory was proposed to freeze cell suspensions, it does not take into account the characteristic features of biological tissue as a complex system of cells and extracellular matrix with unique thermophysical characteristics due to microcirculation and metabolic processes.

Neutrophilic leukocytes, infiltrating the tissues around the primary necrosis area, formed an inflammatory leukocyte shaft or a demarcation area after skin cryodestruction in the wound (Fig. 1). White blood cells are known to appear in the wound just a few minutes after the damage, activate the complement system, interacting with the kallikrein-kinin system, coagulation and fibrinolysis systems, and arachidonic acid derivatives. Partial lyses of a blood clot, bacterial flora, foreign bodies, and tissue detritus occurs in the area of damage under the influence of proteolyses enzymes of neutrophils [15]. 


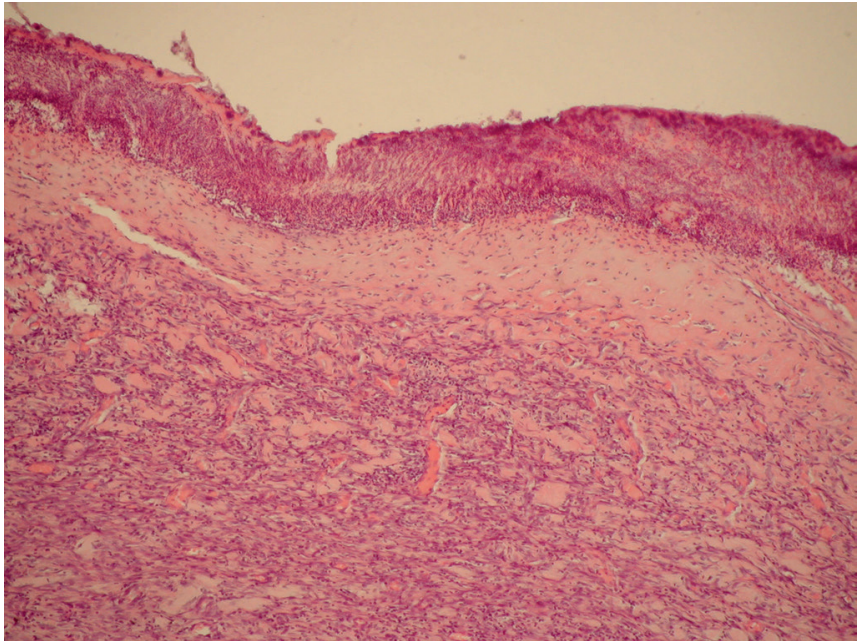

Fig. 1. Group III. 14 days. Structure of wound defect: fragments of necrotic tissue (zone of primary necrosis), the demarcation leukocyte shaft, a layer of necrotic tissue (zone of secondary necrosis), a layer of granulation tissue. Stained with hematoxylin and eosin, $\times 100$.

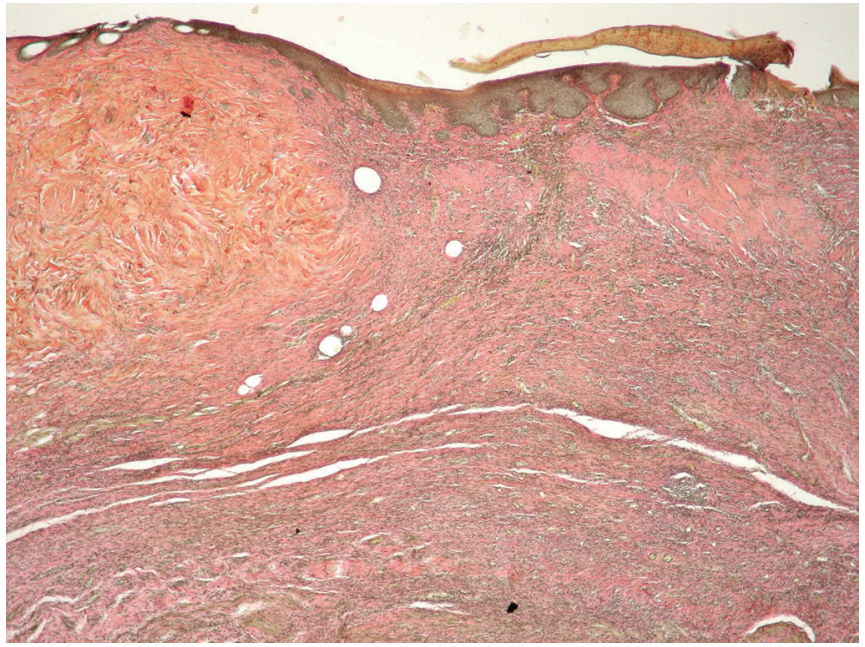

Fig. 2. Group III. 21 days. Complete epithelization of the regenerate zone. The epithelial layer forms superficial and deep acanthotic growths. Stained with picrofuchsin according to van Gieson, $\times 40$.

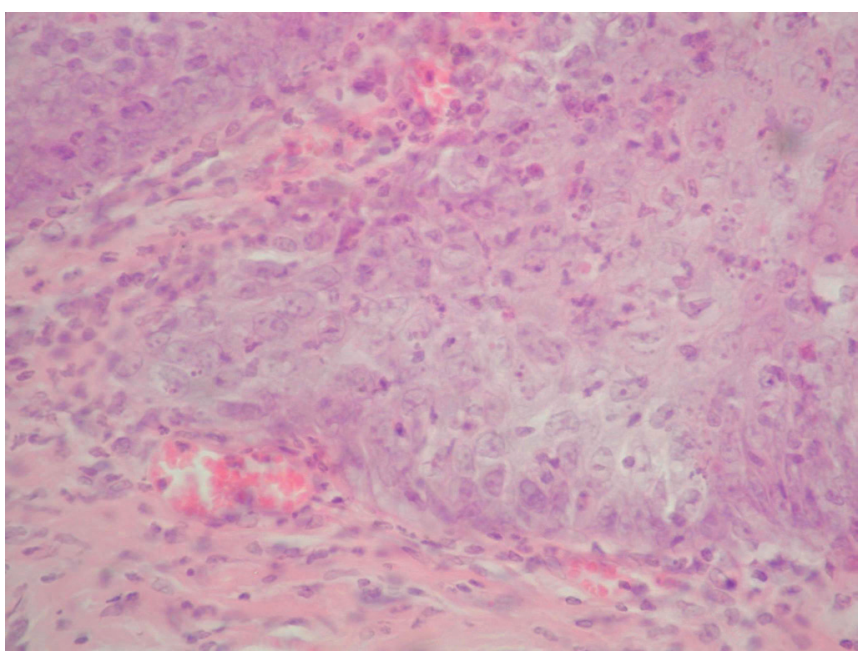

Fig. 3. Group III. 21 days. Increased mitotic activity and mild dysplastic changes in epidermis. Stained with hematoxylin and eosin, $\times 400$.
An area of secondary necrosis was revealed behind the demarcation leukocyte shaft (Fig. 1), represented by necrotic altered fragments of the dermis and hypodermis. It is believed that inflammation reactions occur after the initial low-temperature damage in the tissues. Enzymes, including proteolytic ones, are released from the cells, lipid peroxidation processes are activated and antioxidant defense weakens, active oxygen forms in the tissues, incompletely oxidized metabolic products are formed and acidosis develops. Excessive formation of aggressive products is one of the causes of the emergence and spread of the secondary necrosis area [12]. In addition, development of this area is also associated with hemodynamic disorders [14].

Thus, we can conclude that the contact of the skin with the cryotool applicator was accompanied by dynamic, interconnected changes in temperature fields on the skin surface and in the underlying tissues. Ice front occurred and spread in the tissues. It can be called the main etiological factor in the development of primary tissue necrosis. In areas where the temperature of the tissues did not fall below the cryostability point of the cells, their death, apparently, is due to a wide range of metabolic disorders caused by the indirect effect of cooling on cells functioning. The main etiological factors of such disorders include ischemic disorders caused by thrombosis of blood vessels of the microvasculature, and the inflammatory reaction that develops after warming the tissues.

Behind the zone of secondary necrosis we found a layer of granulation tissue (fig. 1) with vascular, cellular and fibrous components. Their ratio varied, indicating various degrees of maturity at different periods of the experiment.

When analyzing the obtained morphometric parameters in groups II, III with an increase in the duration of the experiment, a significant $(\mathrm{p}<0.05)$ decrease in the thickness of the primary and secondary necrosis area, torus demarcation of leukocytes, and an increase in the thickness of the granulation tissue layer were noted (table 1).

Hereby, the results of survey microscopy and a morphometric study indicate that the healing of cold skin wounds in groups II, III is a complex, dynamic process consisting of characteristic stages (hemostasis, inflammation, proliferation, remodeling), which do not have clearly defined time borders.

In a comparative analysis, it was noted that the healing processes in group III compared with group II at all periods of the experiment were more pronounced and active, as evidenced by the results of the survey microscopy and morphometric studies.

Comparing survey microscopy in group III with group II we observed more intensive cleansing of the wound from necrotic tissue; more active proliferative processes in it with the formation of granulation tissue, characterized by an intensive rate of maturation; in the adjacent wound defect tissues of the dermis, hypodermis with underlying muscle tissue less pronounced hemodynamic disturbances and cell infiltration, characterized by the presence of leukocytes, macrophages, lymphocytes, fibroblast cells. It is known that all reparative processes occur against the background of 
Table 1. Thickness of layers $(\times 10-6 \mathrm{~m})$ of wound defect in groups II and III.

\begin{tabular}{|c|c|c|c|}
\hline \multirow{2}{*}{ Layer name } & \multicolumn{3}{|c|}{ Term of animals withdrawn from experiment, days } \\
\hline & 7 & 14 & 21 \\
\hline \multicolumn{4}{|c|}{ Group II } \\
\hline zone of primary necrosis & $1,975.9 \pm 93.7$ & $\begin{array}{c}1,531.0 \pm 62.5 \\
\mathrm{p}_{1}<0.05\end{array}$ & $579.9 \pm 22.1 p_{1}<0.05$ \\
\hline leukocyte demarcation shaft & $329.5 \pm 33.2$ & $\begin{array}{c}249.8 \pm 15.2 \\
p_{1}<0.05\end{array}$ & $\begin{array}{l}94.6 \pm 5.7 \\
p_{1}<0.05\end{array}$ \\
\hline zone of secondary necrosis & $482.7 \pm 19.0$ & $\begin{array}{c}393.3 \pm 9.2 \\
\mathrm{p}_{1}<0.05\end{array}$ & $\begin{array}{c}203.3 \pm 4.2 \\
p_{1}<0.05\end{array}$ \\
\hline granulation tissue layer & $148.3 \pm 20.4$ & $\begin{array}{c}203.8 \pm 12.6 \\
p_{1}<0.05\end{array}$ & $541.8 \pm 24.0 p_{1}<0.05$ \\
\hline \multicolumn{4}{|c|}{ Group III } \\
\hline zone of primary necrosis & $\begin{array}{c}1,497.0 \pm 47.0 \\
\mathrm{p}_{2}<0.05\end{array}$ & $\begin{array}{c}1,202.9 \pm 35.2 \\
\mathrm{p}_{1}<0.05 \mathrm{p}_{2}<0.05\end{array}$ & $\begin{array}{c}431.9 \pm 9.6 \\
\mathrm{p}_{1}<0.05 \mathrm{p}_{2}<0.05\end{array}$ \\
\hline leukocyte demarcation shaft & $\begin{array}{c}476.6 \pm 19.5 \\
p_{2}>0.05\end{array}$ & $\begin{array}{c}342.4 \pm 15.7 \\
\mathrm{p}_{1}<0.05 \mathrm{p}_{2}>0.05\end{array}$ & $\begin{array}{c}207.1 \pm 15.9 \\
\mathrm{p}_{1}<0.05 \mathrm{p}_{2}<0.05\end{array}$ \\
\hline zone of secondary necrosis & $\begin{array}{c}341.3 \pm 10.1 \\
\mathrm{p}_{2}<0.05\end{array}$ & $\begin{array}{c}260.1 \pm 7.7 \\
\mathrm{p}_{1}<0.05 \mathrm{p}_{2}<0.05\end{array}$ & $\begin{array}{c}160.6 \pm 4.9 \\
\mathrm{p}_{1}<0.05 \mathrm{p}_{2}<0.05\end{array}$ \\
\hline granulation tissue layer & $\begin{array}{c}335.0 \pm 6.5 \\
\mathrm{p}_{2}<0.05\end{array}$ & $\begin{array}{c}441.9 \pm 9.0 \\
\mathrm{p}_{1}<0.05 \mathrm{p}_{2}<0.05\end{array}$ & $\begin{array}{c}776.7 \pm 12.3 \\
p_{1}<0.05 p_{2}<0.05\end{array}$ \\
\hline
\end{tabular}

Note: $p_{1}$ - significance of differences compared with previous term of the animals withdrawn from experiment, $p_{2}$ - significance of differences compared with group II.

Table 2. Thickness of the epithelial layer $(\times 10-6 \mathrm{~m})$ in groups I-III.

\begin{tabular}{|c|c|c|c|}
\hline \multirow{2}{*}{$\begin{array}{l}\text { Group } \\
\text { number }\end{array}$} & \multicolumn{3}{|c|}{ The term of the animals withdrawn from experiment, days } \\
\hline & 7 & 14 & 21 \\
\hline 1 & & $(21.3 \pm 0.7) \times 10^{-6} \mathrm{M}$ & \\
\hline II & $\begin{array}{c}(26.8 \pm 1.2) \times 10^{-6} \mathrm{M} \\
\mathrm{p}_{1}<0.05\end{array}$ & $\begin{array}{l}(32.9 \pm 1.3) \times 10^{-6} \mathrm{M} \\
\mathrm{p}_{1}<0.05 \mathrm{p}_{2}<0.05\end{array}$ & $\begin{array}{l}(39.6 \pm 1.1) \times 10^{-6} M \\
p_{1}<0.05 p_{2}<0.05\end{array}$ \\
\hline III & $\begin{array}{l}(69.9 \pm 2.1) \times 10^{-6} \mathrm{M} \\
\mathrm{p}_{1}<0.05 \mathrm{p}_{3}<0.05\end{array}$ & $\begin{array}{c}(84.3 \pm 2.4) \times 10^{-6} \mathrm{M} \\
\mathrm{p}_{1}<0.05 \mathrm{p}_{2}<0.05 \mathrm{p}_{3}<0.05\end{array}$ & $\begin{array}{c}(98.1 \pm 2.0) \times 10^{-6} \mathrm{M} \\
\mathrm{p}_{1}<0.05 \mathrm{p}_{2}<0.05 \mathrm{p}_{3}<0.05\end{array}$ \\
\hline
\end{tabular}

Note: $p_{1}$ - significance of differences compared with group $I, p_{2}$ - the significance of differences compared to previous period of animal withdrawal from the experiment, $p_{3}$ - the significance of the differences compared with group II.

an inflammatory reaction, which, from the morphological point of view, is divided into leukocyte, macrophage and fibroblastic stages [16]. In a morphometric study in group III compared with group II at all periods of the experiment a significantly $(\mathrm{p}<0.05)$ lower value of the thickness of the primary and secondary necrosis area was noted, significantly $(\mathrm{p}<0.05)$ a larger value of the thickness of the demarcated leukocyte shaft and granulation tissue layer.

The more pronounced regenerative processes in group III compared with group II, were also indicated by the revealed morphological features of the epidermis which was located in the marginal sections of the wound or covered the surface of the regenerate on the 21st day of the experiment. In these areas epidermis formed superficial and deep acanthotic growths in the underlying tissue (Fig. 2). An increase in mitotic activity and moderately expressed dysplastic changes were determined in part of the visual fields in the epidermis (Fig.3). Simultaneous presence of morphological signs of dysplasia and increased prolifer- ative activity of cells causes certain alertness. Assuming that these changes in the epithelium are exacerbated, it is possible to develop severe dysplasia, the combination of which with enhanced proliferation is a characteristic feature of precancerous skin diseases. In order to refute or confirm these fears, it is necessary to study proliferative processes in epithelium with the aim of their qualitative and quantitative assessment.

Initially, a decrease in the synthesis of deoxyribonucleoproteins and the number of mitoses is noted in the damaged epithelium of the wound edges, but after 24 hours the mitotic index and the index of labeled nuclei increase several times. Interestingly, the size of the wound does not affect the width of the mitotic activity area. Proliferation intensity of the epithelium in the area of skin defects is variable, it changes, increasing and decreasing at certain intervals. It is known that the proliferative activity of the epithelium can be inflammatory or regenerative in nature [17].

Hypertrophic and hyperplastic processes were also detect- 
ed in the above areas in the epidermis, which has led to a significant $(\mathrm{p}<0.05)$ increase in the thickness of this layer in groups II and III as compared with group I (table 2). With an increase in the experiment duration the thickness of the epithelial layer in groups II and III increased significantly $(\mathrm{p}<0.05)$, indicating an increase in regenerative processes. This index was characterized by a significantly $(\mathrm{p}<0.05)$ higher value in group III compared with group II.

Re-epithelialization of the wound [18] begins with the migration of epithelial cells from the edges of the wound to the area of the tissue defect within a few hours after tissue damage, continuing throughout all phases of the wound healing. Weakening of intercellular contacts and cell contacts with the basement membrane, formation of peripheral cytoplasmic actin filaments make it possible for epithelial cells to move in the direction of the damaged tissues. As the process of re-epithelialization advances, the basal membrane is re-formed [15].

Keratinocytes adjacent to the lesion area also affect the course of wound healing. Various isoforms of transforming growth factor $\beta$ synthesized by them, as well as platelet growth factor, affect the proliferation of fibroblasts, their migration to the area of damage, and production of extracellular matrix components [15].

We have discovered the enhancement of regenerative potentials in the wound after cryodestruction of the skin in hairless rats, which were injected into the abdominal cavity with an aqueous colloidal solution of C60 fullerenes. From our point of view, it is firstly, due, to the antioxidant activity of fullerenes [12], which prevents damage to cells and tissues by secondary alteration products; secondly, the ability of fullerenes to induce differentiation of fibroblasts [19], which, apparently, leads to the activation of collagenogenesis, rapid filling of a wound defect with granulation tissue with its intensive maturation and transformation into connective tissue.

\section{CONCLUSIONS}

A comprehensive morphological study of the experimental material indicates that the abdominal cavity injection of an aqueous colloidal solution of C60 fullerenes activates reparative processes in the skin cold wound, going through all the classical stages.

C60 fullerenes stimulate proliferative activity in the epidermis, located in the wound marginal regions or covering the regenerate surface, which leads to an increase in epithelial layer thickness by 2.6, 2.6, 2.5 times on 7, 14 and 21 days; promotes faster cleaning of the wound from necrotic tissue, reducing thickness of primary necrosis area on days 7,14 and 21 by 1.3 times by increasing the demarcation area on days 7,14 and 21 by 1.4, 1.4 and 2, 2 times; reduces the thickness of the secondary necrosis area by 7,14 and 21 days by $1.4,1.5$ and 1.3 times; accelerates the filling of the wound defect with granulation tissue, the layer thickness of which increases by 2.3, 2.2 and 1.4 times on the 7 th, 14th and 21 st days, respectively; reduces the severity of hemodynamic disorders and cell infiltration in the wound defect adjacent tissues of the dermis, hypodermis with the underlying muscle tissue.

The prospect of further research is an immunohistochemical investigation to discover the apoptotic and proliferative processes in the wound after skin cryodestruction in hairless rats.

\section{REFERENCES}

1. Abramovits W., Graham G., Har-Shai Y., et al. Dermatological cryosurgery and cryotherapy. Springer-Verlag London. 2019, p.758. DOI: 10.1007/978-1-4471-6765-5_4

2. Mnikhovich M.V., Eremin N.V. Jeksperimentalno-morfologicheskij analiz gistogeneza kozhnoj rany pod vlijaniem nizkointensivnogo lazernogo izluchenija. [Experimental and morphological analysis of histogenesis of skin wounds used to low-intensity laser radiation]. Journal of new medical technologies. 2013.20 (2):113-120. (Ru)

3. Ilyin V.V., Piotrovskii L.B. Issledovanie stabilnosti plenok fullerena $S 60$. [The study of the stability of fullerene (60 films]. Reviews on Clinical Pharmacology and Drug Therapy. 2017;15(2):42-45. doi: 10.17816/ RCF15242-45. (Ru)

4. Kuznietsova H.M., Dziubenko N.V., Chereschuk I.O., et al. Vplyv vodorozchynnyh $\$ 60$ fulereniv na rozvytok gostrogo kolitu u shhuriv. [The impact of water-soluble C60 fullerenes on the development of acute colitis in rats]. Studia Biologica. 2017. 11(1): 41-50. (Ua)

5. Matyshevska 0.P., Prylutska S.V., Grynyuk I.I. Fulereny $\$ 60$ - biologichno aktyvni molekuly. Fizyko-himichni vlastyvosti ta biodostupnist. [Fullerenes $\mathrm{C60}$ - biologically active molecules. Physico-chemical properties and bioavailability]. Biotechnology. 2010. 3(1):18-26. (Ua)

6. Prylutskyy Y.I., Vereshchaka I.V., Maznychenko A.V., et al. C60 fullerene as promising therapeutic agent for correcting and preventing skeletal muscle fatigue. Journal of Nanobiotechnology. 2017. 15:8. D01: 10.1186/ s12951-016-0246-1.

7. Galvan Y.P., Alperovich I., Zolotukhin P., et al. Fullerenes as anti-aging antioxidants. Current aging science. 2017. 10:56-67.

8. Shershakova N., Baraboshkina E., Andreev S., et al. Anti-inflammatory effect of fullerene $(60$ in a mice model of atopic dermatitis. Journal of nanobiotechnology. 2016. 14(8): DOI 10.1186/s12951-016-0159-z

9. Petrovic D., Seke M.,Srdjenovic B., et al. Applications of anti/prooxidant fullerenes in nanomedicine along with fullerenes influence on the immune System. Journal of nanomaterials. 2015. Article ID 565638. DOI: $10.1155 / 2015 / 565638$

10. Kabankov A.V., Ivanov A.S., Mnatsakanov S.S., et al. Osobennosti napravlennoj regeneracii kostnoj tkani pri ispolzovanii rezorbiruemyh membran na osnove polivinilovogo spirta s dobavleniem fullerenov S60. [The peculiarities of the guided bone tissue regeneration on using resorbable membranes based on polyvinyl alcohol with the addition of (60 fullerenes]. Vestnik Vitebskogo gosudarstvennogo meditsinskogo universiteta. 2019. 18(4): 91-97. (Ru)

11. Rondags A., Yan Yuen W., F. Jonkman M., et al. Fullerene C60 with cytoprotective and cytotoxic potential: prospects as a novel treatment agent in dermatology? Experimental dermatology. 2017. 26:220-224.

12. Uspenskaya M.V., Popov V.A., Makin D.N., et al. Primenenie fullerenov $v$ bioaktivnyh ranevyh pokrytijah. [The use of fullerenes in bioactive wound dressings]. Scientific and technical journal of information technologies, mechanics and optics. 2008. 8(2): 78-83. (Ru)

13. Kovalov G.0., Vlasov 0.0., Myroshnychenko M.S. Experimental model of skin cryodestruction. Problems of cryobiology and cryomedicine. 2019;29(1):88-101. 
14. Shafranov V.V., Borhunova E.N., Taganov A.V., et al. Teorija i mehanizm povrezhdenija biologicheskih tkanej pri lokalnom zamorazhivanii. [Theory and mechanism of injury of biological tissues at the local freezing]. Russian journal of pediatric surgery, anesthesia and intensive care. 2011. 1:124-134. (Ru)

15. Mnikhovich M.V., Yeremin N.V., Fomina L.V., et al. Mezhkletochnye i kletochno-matriksnye vzaimodejstvija pri zazhivlenii ran. [Intercellular and cell-matrix interactions in wound healing]. Journal of anatomy and histopathology. 2013. 2(2): 63-83. (Ru)

16. Mnikhovich M.V., Grachev V.A., Yeremin N.V., et al. Ocenka morfologii mikrocirkuljatornogo rusla i ego kletochnogo mikrookruzhenija pod vlijaniem nizkointensivnogo lazernogo izluchenija v uslovijah jeksperimentalnoj rany kozhi. [The evaluation of morphology of the microcirculatory bed and its cellular microenvironment under the influence of low intensity laser radiation in an experimental wound of skin]. Bulletin of Pirogov national medical and surgical center. 2012. 7(1):112-117. (Ru)

17. Serov V.V., Schekhter A.B. Soedinitelnaja tkan (funkcionalnaja morfologija i obshhaja patologija) [Connective tissue (functional morphology and general pathology)]. M. : Medicine, 1981; 312 p. (Ru)

18. Bykov V.L., Leontiyeva I.V., Kulayeva V.V., et al. Tkanevaja, kletochnaja i molekuljarnaja biologija gemostaza i rejepitelizacii pri zazhivlenii ran slizistoj obolochki polosti rta. [Tissue, cell and molecular biology of hemostasis and reepithelialization in the healing wounds of the oral mucosa]. Morphology. 2019. 156 (6): 64-76. (Ru)

19. Castroa E., Hernandez Garciaa A., Zavalaa G., et al. Fullerenes in biology and medicine. J Mater Chem B Mater Biol Med. 2017.5(32):6523-6535. DOl:10.1039/C7TB00855D.

\section{Acknowledgments:}

We would like to express our gratitude to Doctor of Phys. Math. Sciences, Professor Yu.I. Prylutsky (Taras Shevchenko National University of Kyiv) for providing samples of an aqueous colloidal solution of C60 fullerenes.

\section{ORCID and contributionship:}

Oleksandr O. Vlasov - 0000-0002-5570-1598 B,D

Gennadiy O. Kovalov - 0000-0002-5714-6698 A,C,E,F

Mykhailo S. Myroshnychenko - 0000-0002-6920-8374 A,B,F

\section{Conflicts of interest:}

Authors declare no conflict of interest.

\section{CORRESPONDING AUTHOR Mykhailo S. Myroshnychenko \\ Kharkiv National Medical University \\ str. Svetlaya27A, apt. 70, 61129, Kharkiv, Ukraine \\ tel: +380501699763 \\ e-mail: msmyroshnychenko@ukr.net}

Received: 15.10 .2019

Accepted: 20.02 .2020

A - Work concept and design, B - Data collection and analysis, C - Responsibility for statistical analysis,

D -Writing the article, $\mathbf{E}$-Critical review, $\mathbf{F}$ - Final approval of the article 